\title{
The International and
}

\section{Comparative Law Quarterly}

(incorporating the Quarterly of the Society of Comparative Legislation and International Law and the Transactions of the Grotius Society)

\author{
BOARD OF EDITORS \\ General Editor: K. R. Simmonds \\ Assistant General Editor: TOM HARPER \\ P. B. Carter - A. K. R. Kiralfy \\ Norman S. MARSH
}




\section{The International and Comparative Law Quarterly}

\begin{tabular}{llll}
\hline Volume 26 & Part 4 & October. 1977 \\
\hline
\end{tabular}

Essays in honour of

John Humphrey Carlile Morrls

PAGE

FOREWORD

Lord Scarman 701

The Proper Law of Producer's Liability David $F$. Cavers 703

The Incidental Question Revisited: Theory and Practice IN THE CONFLICT OF LAWS

A. E. Gotlieb 734

Policy Controlled State Interest analysis in Choice of

Law, Measure of Damages, Torts Cases

Moffatt Hancock 799

JURISDiction AGREements: SOME REFLECTIONS

Otto Kahn-Freund 825

Reference, Choice, Restriction and Prohibition

D. St. L. Kelly 857

INHERENT Limitations in STATUTES AND THE CONFLict OF LAWS

K. Lipstein 884

The Proposed New law of Exemption Clauses and the CONFLICT OF LAWS

F. A. Mann 903

Contract as a Tort Defence in the Conflict of Laws

P. M. North 914

Some Thoughts on the Proper Law of a Tort P. E. Nygh 932

Marriage in American Conflict of Laws

Willis L. M. Reese 952

New Zealand Conflict of Laws: A Bird's Eye View

P. R. H. Webb and F. M. Auburn 971 


\section{CONTRIBUTIONS AND SUBSCRIPTIONS}

All correspondence, including books for review and business communications, as well as contributions (which must be typed), should be addressed as follows: The General Editor, International and Comparative Law Quarterly, British Institute of International and Comparative Law, Charles Clore House, 17 Russell Square, London WCIB 5DR (01 $6365802-3-4-5)$.

Subscriptions and Orders should be sent to the British Institute of International and Comparative Law, at the above address.

Contributions to the International and Comparative Law Quarterly express the vlews of their authors and not necessarily the views of the Editorial Board or of the British Institute of International and Comparative Law.

\section{Index to Volume 26}

The Annual Index to the Quarterly is normally included in Part 4 of the relevant volume, but in view of the fact that Part 4 on this occasion is a special issue, the index to Volume 26 will be distributed with Part 1 of Volume 27. 


\section{Essays in honour of \\ John Humphrey Carlile Morris}

The Editors take great pleasure in devoting this issue of the International and Comparative Law Quarterly to a collection of essays written in honour of Dr. J. H. C. Morris. They would like to acknowledge their indebtedness to Dr. Peter North for his help in initiating this project. 
